\title{
Educating for global citizenship: Australia as a case study
}

\author{
Ruth Reynolds, Suzanne MacQueen* and Kate Ferguson-Patrick - University of \\ Newcastle, Australia
}

\begin{abstract}
Twenty-first-century teaching prepares students for a globalized existence. The long-established goal of schooling to prepare a responsible citizenry who strive for the benefit of the community must now be extended, assisting students to become global citizens, equipped to deal with global issues. This article investigates how civics and citizenship education is addressed in curricula; in particular, to what extent the ongoing issue of supporting a critical citizenry, locally and globally, is addressed. Using Australia as a case study, we present an analysis of selected Australian primary school (ages 5-12) curriculum documents to determine the extent of commitment to educating for global citizenship specifically. While intentions are good, work is needed to ensure that these are enacted within schools.
\end{abstract}

Keywords: global citizenship; interdisciplinary teaching; curriculum for citizenship; participatory citizenship; primary school education

\section{Introduction}

Teaching for the twenty-first century means that the issues of globalization, including technological interconnectedness and international imperatives such as climate change, can be addressed by an informed and engaged citizenry. Our student citizens can participate at local, national and global levels - and social media and global communications allow them to do this more freely - but are they well equipped to do so? Schooling that addresses the issues of the wider world, and equips students to contribute to their world, locally and globally, is a basic right of national citizenship. This study scrutinizes the opportunities provided by Australian primary school curriculum documents in primary schools, using an Australian case study, to teach twenty-firstcentury global citizenship capacities, and in particular the capacity to actively engage with global issues. Our research question is:

In what ways do primary school curriculum documents require, provide and/or limit opportunities for teachers to educate for global citizenship?

\section{Definitions: Citizenship education, global citizenship, global education and global citizenship education}

Scholarship on citizenship education, global citizenship, global education and global citizenship education often emphasizes the existence of multiple and competing approaches in schools. Citizenship education primarily provides students with understanding about why and how their society works. It is not only about transmitting 
cognitive capital, but also culture and key values, customs and traditions, establishing national identity and affinity, and action to promote democratic ideals in one's own nation (Marshall, 1964; Aspin, 2002; MCEETYA (Ministerial Council on Education, Employment, Training and Youth Affairs), 2006; Crick, 2007; Banks, 2008; Osler, 2011; UNESCO (United Nations Educational Scientific and Cultural Organization), 2014). Global citizenship, however, has increasingly become of interest in national civics and citizenship education curriculum documents. For example, the International Civic and Citizenship Education Study (ICCS) 2016 comparative study of student knowledge, perceptions and activities in 94,000 lower secondary students in 24 countries signals some change in perceptions, with a focus on environmental sustainability in civics and citizenship education, social interaction at school and the use of social media for civic engagement (Schulz et al., 2018).

Global citizenship and education for global citizenship emphasize the impact of international globalization on identity, how individuals develop allegiances, and implement their civic responsibilities as a result of these global processes. Goren and Yemini (2017) and Rapoport (2017) provide a comprehensive overview of the research undertaken in global citizenship education, but point to the lack of an agreed definition of global citizenship and global citizenship education. Carano (2013), Goren and Yemini (2017), Rapoport (2015), Reynolds (2015) and Schweisfurth (2006) argue that global citizenship education is influenced by the teacher and context in which it is taught, and so expecting consensus is probably unrealistic.

Global education as 'preparing students for the increasing interconnectedness among people and nation' (Zong et al., 2008: 199) is often explored, but in its implementation there is considerable philosophical variation from the idea of a multifaceted multidimensional citizenship embodying personal, social, spatial and temporal dimensions (Cogan and Grossman, 2009) to one comprising knowledge, consciousness, intercultural awareness, transnational efficacy and informed advocacy (Lorenzini, 2013). Themes of human rights, equity, conflict resolution and social justice are evident (Osler and Vincent, 2002). Critical global education supports curricula that foster critical dialogue and action on global issues (Subedi, 2010). Valuing marginalized knowledge such as third world traditions and perspectives (Merryfield, 2010) is also advocated.

UNESCO (2014) points out that the key tension in the field is a need to allow individual, singular identity and participation while also promoting universality with common and collective identity and participation. Global citizenship is not a legal framework, but is about belonging to a broader community and common humanity, and adhering to universal values (UNESCO, 2014), involving cognitive, socio-emotional and behavioural approaches (UNESCO, 2015). Ascertaining some of the other polarities in the field can help to explain the frictions and help teachers and those interested in school curricula to clarify their positions. Nussbaum (2009) argues that essentially education is either for freedom or for profit. Pike (2015) takes that as a guide for his notion that global education themes can be scrutinized from the perspective of whose interests are best served, the already privileged or the larger mass of society. This theme is evident in the postcolonial discourse work of De Oliveira Andreotti (2011), De Oliveira Andreotti and De Souza (2012), Camicia and Franklin (2011), and Martin and Pirbhai-Illich (2015). Westheimer and Kahne (2004) provide guidance as to the politics of citizenship education broadly based, by questioning the foundations of what is taught and how it is taught in democracy education. They see citizenship education as focused on the personally responsible citizen, the participatory citizen, or the justice-orientated citizen, and although they do not address global citizenship 
education specifically, these overriding themes emerge in many studies addressed here. Teachers choose a focus, and adapt their global citizenship education teaching using guidance from the curriculum, but also react to their context and beliefs. Oxley and Morris (2013) provide a categorization of two broad groups of global citizenship approaches. Cosmopolitan approaches are more individual, such as learning about others and clarifying differences in terms of political, moral, economic and cultural aspects of global citizenship, while the advocacy approaches (anti-individualistic) include social, critical, environmental and spiritual approaches. Thus, clarifying for teachers the various stands they could take in this area may help them to decide how well they are implementing global citizenship education and whether they explore possibilities afforded to them by the curriculum or adhere to what is actually mandated by key statements.

\section{Global citizenship in the school curriculum}

Civics and citizenship education is located differently in the various national school curriculum documents, but it is of interest that most nation states have a focus on civics and citizenship education not because of a romantic attachment to the nation state, but because primarily most major decisions of government linked to everyday citizens' lives (such as transport, education and housing) are made at the national level (Kennedy, 2012). Global citizenship education is correspondingly seen as a series of topics added to the human and social sciences section of the curriculum (UNESCO, 2014; Schulz et al., 2018). Of course, there are increasingly new forms of citizenship that are wider ranging, such as European Union citizenship, but, as Kennedy (2012: 125) points out, the two sit together rather than act as opposing forces:

The focus on human rights in the civic and citizenship education curriculum of many countries is a reflection of commitments to classical liberalism and individual freedom. While there are many international policy instruments that seek to safeguard these rights, the best protections (and indeed the worst abuses) come from within the borders of nation states.

Despite the variety of ways in which civics and citizenship education and global citizenship education can be incorporated in the school curriculum, structural and pedagogical challenges persist in implementation. Challenges to implementation in the school curriculum include teachers' workloads, an exam-orientated educational culture, lack of leadership when clarifying opportunities for trans-disciplinary curriculum and limited pedagogical materials to develop capacity for global citizenship education (UNESCO, 2014). Oxfam, an influential UK-based non-governmental organization (NGO), argues that a key aspect of their social justice and human rights approach to addressing problems in the developing world is to encourage and provide resources in schooling to assist teachers to develop global citizens who learn, reflect and participate in the world (Bourn, 2016). Oxfam UK (2015: 5) espouses three educational principles for schooling - learning, thinking and acting:

Learn: exploring the issue, considering it from different viewpoints and trying to understand causes and consequence.

Think: considering critically what can be done about the issue, and relating this to values and world views and trying to understand the nature of power and action. 
Act: Thinking about and taking action on the issue as an active global citizen, both individually and collectively.

Bourn (2016) argues that Oxfam's approach is important because it assumes that a global citizen is involved in, and has a relationship to, the world, and its message is delivered through state instrumentalities - classroom teachers. The Asia SocietyOECD conception of a globally competent citizen (Colvin and Edwards, 2018), which will be tested as part of international PISA tests (OECD, 2018), includes intercultural education, global citizenship education, twenty-first-century skills, deeper learning, and social and emotional learning. Print (2015), however, argues that given the lack of exposure to global citizenship in current school curricula, it is highly unlikely that global conceptions of citizenship education will be evident in schools. To some extent, this latter observation is dependent upon whether some of the pedagogies of global citizenship are used in schools, as global citizenship is not only about learning about the world and its interdependence with regard to key local, national and global issues, but also requires a transformative pedagogy (UNESCO, 2014).

\section{The pedagogy of global citizenship}

Pedagogy is the art and science of educating, focusing on learning and teaching (Loughran, 2006). There is a need to identify some fundamentals of the unique pedagogy of global citizenship education if an assessment of when it is demonstrated in a curriculum is to be made. Some direction is provided by the research associated with twenty-first-century teaching, intercultural and technology education, and social and emotional learning, which are identified by Boix Mansilla and Jackson (2011) and OECD (2014) as approaches for global competence. Whether we approach global education from a cosmopolitan or an advocacy position (Oxley and Morris, 2013), it may be that skills learnt in classrooms prepare students for global citizenship even when not directed towards global themes. Certainly, statements such as 'global citizenship education (GCE) inspires action, partnerships, dialogue and cooperation through formal and non-formal education' (UNESCO, 2014: 15) imply curriculum-distinct global citizenship pedagogy.

Boix Mansilla and Jackson (2011) argue that key global competences for global students are: the ability to investigate significant problems beyond their own immediate environment; recognize others' perspectives and communicate with diverse audiences; and participate thoughtfully to improve their world. To develop these, teachers must lead students to develop arguments, provide research questions, analyse and synthesize arguments, examine multiple perspectives and clarify the implications of these perspectives. Students must practise communication with diverse communities verbally and non-verbally, and use appropriate technology. Teachers also need to choose topics and issues to study that link the local to the global. Strategies to be used in classroom pedagogy include group work, cooperativebased project work, organized discussions, structured debates and service learning, along with a range of activities that support openness and respect for people from different cultural backgrounds and global mindsets (OECD, 2018), with emphasis on students' sustained engagement and action with real-world events. It is innovative interdisciplinary work, often involving collaboration and negotiation with diverse groups of people (Barron and Darling-Hammond, 2008), that encourages deep learning, including partnerships between teachers and students that focus learning 
on knowledge creation and purposeful use of that knowledge (Fullan and Langworthy, 2014), and critical problem-solving (Scott, 2015). However it appears that, although there are many examples where this learning is taking place, the transmission model of education still prevails as the dominant instructional approach throughout much of the world (Saavedra and Opfer, 2012). In the most recent ICCS tests, the most common teaching techniques used include textbooks, lectures and discussion around current issues, while use of projects, role plays and student-led activities are least used (Schulz et al., 2018). A transmission model of education is unlikely to achieve these twenty-first-century goals. Voogt and Roblin (2012) argue that, although many nations were promoting twenty-first-century competences, with an underlying focus on information and communications technology (ICT) competence, and emphasis on pedagogy such as cooperative learning, problem-based learning and formative assessment in their curriculum documents, the classroom implementation is less encouraging. Citizenship is seen as a key competence, but formal strategies to develop skills for citizenship (and other competences) need to be augmented by activities outside school, or at least linked to the outside world. As Lingard and Keddie (2013: 429) state, the pedagogies required in schools, that make a difference, should be pedagogies that 'privilege and work with students' identities and funds of knowledge in ways that avail the sense of individual and collective political agency that is requisite to nurturing active citizenship'.

Thus, teachers are creative change agents, not only by using technology, but by focusing on multiple approaches to build communities inside and outside schools, and to deliberate on real-world problems. Teachers can help learners make important changes for the betterment of society by tackling issues such as human rights, identity and place in the world (Bourn, 2016). Global citizenship education moves beyond describing and scrutinizing exotic images of the world to coming to grips with real issues, such as learning 'to reflect on how they and their nations are implicated in local and global problems and to engage in intercultural perspectives' (Pashby, 2012: 9). This evokes the notion that classroom teaching strategies should pursue analytic, synthesizing and evaluative approaches to truly promote global citizenship education. Pashby (2012: 9) argues that global citizenship education must address its colonial legacies and the complicity of 'the West' in what are being constructed as 'global' problems but are understood as 'Third World' problems. Varadharajan and Buchanan (2017) point out that educators for global citizenship have a need for a sense of agency and efficacy - a capacity to do something significant and worthwhile to address global inequality - and the national curriculum documents must enable this (MacQueen and Ferguson-Patrick, 2015). However, as indicated by Rapoport (2015), without clear guidance, teachers face curricular insecurity that could result in untested classroom diversity in approach.

This researched scrutiny of the Australian curriculum documents is thus a first step in establishing the opportunities available for Australian teachers to educate for global citizenship, and can provide guidance for teachers when stepping outside strict curriculum guidelines (Osler, 2011). Our research undertook a systematic textual analysis of sections of the primary school curriculum to clarify key themes associated with developing global citizenship. Our research question became:

In what ways do primary school curriculum documents require, provide and/or limit opportunities for teachers to educate for global citizenship? 


\section{Methodology}

The Australian curriculum (ACARA (Australian Curriculum Assessment and Reporting Authority), 2011) reflects the position adopted in the Melbourne Declaration on Educational Goals for Young Australians (MCEETYA, 2008: 9) that we should develop 'responsible global and local citizens', and enable active and informed citizens who 'are able to relate to and communicate across cultures, especially the cultures and countries of Asia; work for the common good, in particular sustaining and improving natural and social environments; [and] are responsible global and local citizens'. There is an obvious global citizenship orientation for this curriculum, and there is an imperative in Australia, a culturally diverse society with many separate links to global sites and ideas, to ensure a fair and engaged society (Australian Human Rights Commission, 2014).

To answer our research question, we undertook a systematic textual analysis (Fairclough, 2003) of three primary school curriculum areas. The Australian curriculum discipline-based learning content is organized into six mandated areas (English; mathematics; science; the arts; humanities and social sciences (HASS); and technologies) from Foundation to Year 6 - the primary years of schooling (ACARA, 2017 (Version 8.3)). Global citizenship is most closely aligned with the HASS curriculum, so that was obvious to include. Given the focus on standardized testing (NAPLAN testing in Australia), and the resultant increased amount of school time often ascribed to English, we thought it was important to scrutinize that curriculum document. We chose science as a third curriculum area for two reasons. First, in previous research we found nothing identified in science, mathematics or digital technology curriculum documents on intercultural competence (Ferguson-Patrick et al., 2018). We therefore wanted to see whether other aspects of global citizenship were evident in at least one science, technology, engineering and mathematics (STEM) subject. Additionally, with HASS receiving less focus in classrooms worldwide (Heafner and Fitchett, 2015), knowing whether global citizenship was evident in STEM classrooms would potentially reduce our concerns that students may be exposed to little or no citizenship education. By investigating the three curriculum areas, we hoped to see how pervasive global citizenship was throughout the Australian primary school curriculum.

We limited our analysis to sampling the curriculum to make the data collection manageable. We chose Year 3, as the Australian curriculum introduces civics and citizenship as a third strand in HASS in that year, so clearly it is deemed important by ACARA at that stage. We added the final year of primary (Year 6), when students often undertake leadership and therefore citizenship roles within schools, and studies around federal government. We wanted to see what changes may occur in global citizenship education across the upper primary level.

All Australian curriculum syllabuses are available online (www.australiancurriculum. edu.au/). For each year, a Year Level Description is provided, summarizing the curriculum in that subject. Each area has a number of organizational strands. For example, English has language, literature and literacy. Each strand has a number of Content Descriptors, including the knowledge and understandings ( $\mathrm{K}$ and $\mathrm{U}$ ) and inquiry and skills (I and $\mathrm{S}$ ) to be covered, all of which are compulsory. These are outcomes that students attain through teaching and learning experiences. There is also an option to view Elaborations, which provide ideas for how to teach the Content Descriptors. The pedagogy of the classroom is for the teacher and the school to clarify and decide upon. Our aim was to find global citizenship content and pedagogy. We used phrases, individual words, and overall assemblage of ideas from various global citizenship education approaches, 
formulated through a comprehensive literature review, to synthesize some key fundamental themes (see Barron and Darling-Hammond, 2008; Boix Mansilla and Jackson, 2011; Bourn, 2016; Goren and Yemini, 2017; OECD, 2018; Oxfam UK, 2015; UNESCO, 2014; Varadharajan and Buchanan, 2017). We collated themes that emerged often, and synthesized these into a few key indicators, acknowledging the plethora of ideas as to what global citizenship is, and clarifying what ideas might be best identified in a curriculum document. Recognizing that these concepts may be present without the specific wording, we then compiled a list of synonyms for each word/phrase (see the Appendix) and put each phrase and word into the documents' search function. We recorded each relevant appearance and the section of the document in which it appeared, whether in the Year Level Description, a Content Descriptor, Elaboration, or Assessment Standards. Finally, we determined which concept each mention was best aligned with.

We then reduced these to a few key indicators that explicitly indicated an opportunity for global citizenship education or provided an avenue for a creative teacher to focus on global citizenship education. We used the themes below as our guide:

1. learning to extend the capacities provided by national citizenship to become global citizens who learn, reflect and participate in the world

2. addressing issues by critical examination

3. enjoying sustained engagement with real-world events

4. working in an interdisciplinary approach

5. collaborating and negotiating with diverse groups of people

6. using technology to build these capabilities.

Analysing mentions of global citizenship content and pedagogies in this way allowed us to determine the extent to which global citizenship is incorporated into the Australian curriculum (at primary level) in terms of quality and quantity, how global citizenship had been constructed, and which aspects, if any, are privileged. It also allowed us to evaluate the likely effectiveness and potential of teachers to facilitate the development of global citizens in delivering the Australian curriculum.

\section{Global citizenship education and the Australian curriculum: HASS, English and science}

The rationale for the HASS curriculum is that it engages 'students' curiosity and imagination about the world they live in and empowers them to actively shape their lives; make reflective, informed decisions; value their belonging in a diverse and dynamic society; and positively contribute locally, nationally, regionally and globally' (ACARA, 2017 (Version 8.3): n.p.). All five of its aims are relevant to our global citizenship education themes. For example, it indicates the need to study 'key historical, geographical, civic and economic knowledge of people, places, values and systems, past and present, in local to global contexts' (ACARA, 2017 (Version 8.3): n.p). The HASS curriculum has four sub-strands: history; geography; civics and citizenship; and economics and business. The civics and citizenship sub-strand, introduced in Year 3, contains the most content related to both national and global citizenship, with many Elaborations very relevant to global citizenship education. It specifies the need to engage with the world as a required aspect. 
The rationale for the study of English is that it:

is central to the learning and development of all young Australians. It helps create confident communicators, imaginative thinkers and informed citizens. It is through the study of English that individuals learn to analyse, understand, communicate and build relationships with others and with the world around them. (ACARA, 2017 (Version 8.3): n.p.)

The aims are to develop competence in communication in all facets of English, and to appreciate literature from the English-speaking world. From our analysis, the study of English assists skills of critical analysis, perspective taking and communication, with a view that students are potential or future citizens, citizens in waiting, being prepared for the real world, but not necessarily encouraged to engage with it. The English curriculum prepares students for the global world in some ways but does not give them license to venture into it. It provides opportunites that could be used in a global world.

The rationale for science is that 'the curriculum supports students to develop the scientific knowledge, understandings and skills to make informed decisions about local, national and global issues' (ACARA, 2017 (Version 8.3): n.p.). Its seven aims focus on scientific inquiry skills and dispositions, and include: 'an ability to solve problems and make informed, evidence-based decisions about current and future applications of science while taking into account ethical and social implications of decisions' (ACARA, 2017 (Version 8.3): n.p.). Science has three interrelated strands: science understanding; science as a human endeavour; and science inquiry skills. We expected and found that global citizenship would feature more highly under science as a human endeavour, but there is little application to real-life situations where students can be actively engaged in either the Content Descriptors or the Elaborations. Students are required to be onlookers to issues in the world. For clarification, we provide examples below from each curriculum area as they address the six themes identified. All quotations are taken from Australian curriculum Version 8.3 (ACARA, 2017), with no page numbering.

\section{Discipline-specific global citizenship references}

\section{Developing the capacity to become global citizens who learn, reflect and participate in the world}

In HASS (Year 3) there is more emphasis on citizenship in relation to students' own Australian community, rather than as global citizens, with a focus on capacity building for citizenship generally. Students are also asked to 'reflect on their learning to suggest individual action in response to an issue or challenge'. Global citizenship is well addressed in Year 6, with a key inquiry question in the civics and citizenship strand being 'How has Australia developed as a society with global connections, and what is my role as a global citizen?'. In Year 6, students 'examine Australian citizenship and reflect on the rights and responsibilities that being a citizen entails', and 'explore the obligations that people may have as global citizens'. In English, students participate in a range of communication opportunities, and engage deeply with ideas and information, such as through 'clarifying and interrogating ideas'. Most of this engagement is limited to considering and reflecting, rather than active participation, the exception being that students are to communicate with 'peers and teachers' in Year 3, while for Year 6 students this extends to 'community members'. The science curriculum includes much reflecting and learning about the world. There is thus a mandate provided by the curriculum and teaching practices to support this theme in HASS. In English, students 
could conceivably address this theme, so there is an opportunity provided, but it is not required. In science, although there are opportunities, these are mostly evident in the teaching suggestions (Elaborations), not as requirements.

\section{Addressing issues by critical examination}

Building on the possibilities for a global citizenship focus, the HASS curriculum specifically provides opportunities, and indeed imperatives, to address citizenship issues critically. It is evident when Year 3 students are asked to 'reflect on learning to propose actions in response to an issue or challenge and consider possible effects of proposed actions', and in Year 6 there are examples where students should reflect on what they have learnt about an issue, and identify problems that might be experienced when taking action to address it. Thus, HASS provides mandated requirements to address this aspect of global citizenship. In English, there is no requirement for students of either year to act on issues. When 'differentiating between reporting the facts ... and providing a commentary' (Year 6), they are using the required skills for critical examination, and both years provide opportunities for students in English to develop their critical capacities, but not necessarily to apply them to current or globally focused issues. So there is an opportunity provided, but it is not a requirement, and because issues are not clearly spelled out, the curriculum limits the opportunity for a critical examination of texts.

In science, critical examination of issues is easily linked to our third theme, 'Enjoying sustained engagement with real-world events' (discussed below), with issues such as 'sustainable sources of energy' being a focus (Year 6), asking students to use skills of reflecting, asking questions and investigating. There is no specific requirement to take action, although it could be an opportunity for students to make some suggestions about actions to address the issues.

\section{Enjoying sustained engagement with real-world events}

Our third theme allows even more in-depth scrutiny of the issues associated with global citizenship education by focusing on how much classrooms emphasize the real world. As noted above, science is strongly linked to the real world, and in the HASS curriculum there are plenty of real-world teaching suggestions provided, but with less prescription for this to happen in the Content Descriptors. For example, one key knowledge and understanding concept in Year 6 is 'The obligations citizens may consider they have beyond their own national borders as active and informed global citizens'. Suggestions include using 'a current global issue (for example, immigration across borders or clearing native forests to establish palm oil plantations) to discuss the concept of global citizenship'. In contrast, English includes possibilities in reading texts about real-world topics and topics of interest, including 'everyday, community, informative texts' and texts exploring 'themes of interpersonal relationships and ethical dilemmas within real-world settings'. This is also the approach towards our fourth theme, with references to students exploring texts and topics 'being studied in other areas of the curriculum'. The real world is required in all three areas of the curriculum, but opportunities are less evident.

\section{Working in an interdisciplinary approach}

Year Level Descriptions (Years 3 and 6) in HASS refer to students exploring different types of texts that could link to other subject areas, possibly in English as indicated above, but indeed HASS is truly interdisciplinary as a learning area in itself. Interdisciplinary 
approaches are not readily apparent in science, although three strands (science understanding, science as a human endeavour, and science inquiry skills) are to be 'taught in an integrated way', but without mention of integrating other subject areas. Interdisciplinary approaches can be seen as opportunities rather than being explicitly supported, and this is a limiting factor in itself. There are many lost opportunities in the curriculum documents to provide ideas and strategies for interdisciplinary work.

\section{Collaborating and negotiating with diverse groups of people}

The collaborative focus is strong in both HASS and English, although not evident in science except when students are exhorted to work with other students. In HASS, skills for cooperating and negotiating are evident, despite the absence of these as search terms in the syllabus. The document provides the opportunities, but the teaching suggestions are much stronger in terms of global citizenship education. In English (Year 3), several Content Descriptors and Elaborations mention skills such as 'turntaking', 'roles and collaborative patterns' and Level Description and Content Descriptors (Year 6) encourage students to 'challenge others' ideas', 'contribute to discussions' and 'use interaction skills'. None of these, however, specify that the collaborating should take place with diverse groups or individuals. When students communicate with classmates, teachers, other schools or community members, diversity may or may not be present. Once again, there is a level of skill development that may or may not be open to a global citizenship education focus. No requirement to work with diverse communities is stated.

\section{Using technology to build these capabilities}

Technology use is less global or creative in HASS, but seems focused on skills for compiling and presenting information. In both years, students are expected to access, use and create digital texts. In English, using technology is demonstrated in both years, with students expected to access, use and create digital texts, often through 'multimodal' texts. Again, the technological skills and knowledge addressed will provide students with useful skills in technology which could be used for citizenshiprelated activities, if the teacher applies those skills in an interdisciplinary manner to world issues. In science, technology is only evident in the use of digital technology to 'observe measure and record data with accuracy using digital technologies as appropriate'. Technology is thus used differently in the different learning areas and overall is an opportunity, not a requirement. Technology appears to be positioned as skill development and not an approach to global citizenship itself.

Thus, HASS is a learning area that focuses on developing student dispositions required for effective participation in everyday life, now and in the future, including critical and creative problem-solving, informed decision-making, and responsible and active citizenship. The curriculum statements also claim that HASS empowers students to shape change by developing a range of skills to make informed decisions and solve problems. However, few Elaborations in the syllabus demonstrate this. If a teacher addresses Content Descriptors without considering the Elaborations, opportunities to fully incorporate active and participatory global citizenship education may be missed. A particular strength of English in developing citizenship skills is its focus on both communicating and collaborating, and engaging with relationships and real-world ethical dilemmas in texts, but once again there is an opportunity but not an imperative. Science can contribute greatly to global citizenship education, as it already includes study of global issues, and, with its scientific inquiry approach, it is a problem-based 
and problem-solving subject. The need and opportunity for participation are evident, but again there is no specific requirement. What is perhaps most missing from a citizenship viewpoint is the notion of personal, national or international culpability as a global citizen.

\section{Discussion}

Our scrutiny of the three curriculum areas demonstrates the potential for each to provide different and complementary perspectives, particularly in terms of a transformative and participatory global citizenship pedagogy, but there is a need for this potential to be better realized. Our research question - In what ways do primary school curriculum documents require, provide and/or limit opportunities for teachers to educate for global citizenship? - can be answered in the Australian primary school context by saying that it is an opportunity lost. There is obviously much scope to broaden the curriculum focus to global citizenship, and a critical global citizenship, but there is only tentative interest in doing so.

We have clarified the different perspectives provided by different learning areas on the overall focus of global citizenship. In synthesizing the analysis of the three areas, two main themes arise as key indicators of capacity to educate for global citizenship: pedagogy of global citizenship, and purposeful participation.

Pedagogy (the art and science of educating, focusing on learning and teaching (Loughran, 2006)) is a key theme in this scrutiny of curriculum documents because it is often touted as a true focus in global citizenship. It is not just about what you learn, but also about how you learn (Colvin and Edwards, 2018). Global citizenship is enhanced via technology, and the distinct pedagogy relevant to the manner of inclusion of ICT as a communicative tool in the curriculum is an important indicator of global citizenship (Print, 2015). Additionally, the limited promotion of interdisciplinary approaches to global citizenship education is of concern when interdisciplinary approaches are also seen as a key focus and signifier of global citizenship education (Boix Mansilla and Jackson, 2011). Both English and HASS require students to use digital tools to create digital or multimodal texts, and HASS also promotes the use of digital technologies for gaining and organizing data. In science, there is surprisingly little emphasis on technology, except occasional reference to using a digital tool. ICT therefore appears as a tool to be used predominantly for receiving or transmitting information, rather than for solving problems or building links across communities (Scott, 2015). Interdisciplinary approaches to learning (Barron and Darling-Hammond, 2008) are promoted in the curriculum documents, but in limited ways. HASS models internal integration of its own strands (history, geography, civics and citizenship), while arguing that it be should be taught in an interdisciplinary manner with links to English. In English, students explore texts from other areas of the curriculum. Science again demonstrates the least interdisciplinary approach, as it brings its own sub-strands together but rarely refers to any other learning area (Ferguson-Patrick et al., 2018). Given that the world's problems are rarely confined to one discipline, this approach is unlikely to yield optimal results for global citizenship (Ferguson-Patrick et al., 2018). The opportunities to build real-world, authentic learning opportunities are not clearly evident. Despite this, an innovative teacher could promote them.

Purposeful participation reflects the intended outcome of global citizenship, that students take action that can transform the world. The focus of advocacy (Oxley and Morris, 2013) is, however, missing from the discourse. Justice-orientated approaches are not really evident, except as an opportunity that the teacher can incorporate when 
issues are seen as important (see HASS curriculum). Students in HASS explore realworld events and current global issues, and natural disasters are studied in science, but without reference to human intervention, except with regard to sustainability. HASS provides the most scope for participating in society (Boix Mansilla and Jackson, 2011; OECD, 2018), where community action is advocated, especially in Year 6, and in the strand of civics and citizenship. It is implied that science can make a better world, but there is no clear perspective on how. There is certainly a lost opportunity for teachers to use the science curriculum to work with HASS and English to solve real-life problems, unless the teacher makes that opportunity (see examples in Osler, 2011).

The communication skills developed in English could possibly be used to bring about change, but this is not required of students. Transformative action is therefore only evident in the HASS curriculum, and previous research has shown that purposeful action is largely missing from curriculum and classroom practice, for a variety of reasons (MacQueen and Ferguson-Patrick, 2015). Therefore, a limited perspective is presented in schools as to who can achieve change in our world and how. The curriculum documents are not likely to change the teacher practices seen by Voogt and Roblin (2012).

\section{Conclusion}

Our scrutiny of these documents indicates that fundamental tenets of being a global citizen - such as learning to act when issues require it, to address fundamental realworld problems in an interdisciplinary manner, and to have a future view for the world where students are encouraged to consider how to transform society to create a better world - are not fundamental in the content and pedagogy of the Australian curriculum. Australian school students remain citizens in waiting: they can influence their world when they get older.

All three curriculum areas mention group work and collaboration, and developing the capacity to interact with others was evident (particularly in HASS), but there was no real notion of why, except where intercultural competence is mentioned (in HASS). An expanded notion of diversity is not clear, which is problematic in a country that prides itself on its multiculturalism, fairness and inclusivity. The skills to avert racism, to learn new things, to engage, to find other ways, and to create a safe and supportive society can be greatly enhanced. In English, clarifying and analysing different perspectives provided in literature is present, but with no real sense of why that matters. Technology is seen as a tool or an object of scrutiny, but there is no analysis or sense of the change that technology makes to the notion of global citizenship.

To enact global citizenship education, teachers require opportunities from a curriculum. Although the Australian curriculum supports teachers to address some aspects of global citizenship, there is much more it could do to require teachers to advocate for a better world, and to address key issues such as justice and equality, and both individual and collective identities on a global scale. There is scope for themes such as postcolonial histories from a global perspective, media studies from an equity and critical perspective, and an appreciation of the role that science (and other STEM disciplines) can play in promoting the skills necessary for a globally competent young citizen. Providing school students with the opportunity to envisage a better world and a way to achieve it would seem to be a fundamental focus for education, and our teachers need to see this as an opportunity in the curriculum. 


\section{Notes on the contributors}

Ruth Reynolds is Associate Professor of primary school education at the University of Newcastle, Australia, where she focuses on global education, citizenship education and innovative pedagogies in classroom teaching. She is author and/or editor of ten books for teachers and numerous teaching resources, and has participated in several national and state curriculum initiatives. In 2013, she was awarded an Australian Award for University Teaching with a citation for Outstanding Contributions to Student Learning for contribution to the humanities and social sciences area of the curriculum. Her latest book is the fourth edition of Teaching Humanities and Social Sciences in the Primary School (Oxford University Press, 2018).

Suzanne MacQueen is Senior Lecturer in education at the University of Newcastle, Australia. Her research focuses on issues of social justice in education. She is a member of the Global Education Research and Teaching (GERT) team, focusing on the promotion of, and research into, teaching for the development of global citizenship. She has published several journal articles and book chapters from her work with GERT, as well as her own individual research.

Kate Ferguson-Patrick is Senior Lecturer in education at the University of Newcastle, Australia. Her research focuses on cooperative learning as a culturally responsive pedagogy and democracy classrooms in an intercultural world. She is a member of the Global Education Research and Teaching (GERT) team, focusing on the promotion of, and research into, teaching for the development of global citizenship. She has published several journal articles and book chapters from her work with GERT, as well as her own individual research. Her latest co-authored book is Cooperative Learning for Intercultural Classrooms: Case Studies for Inclusive Pedagogy (Routledge, 2018).

\section{References}

ACARA (Australian Curriculum Assessment and Reporting Authority) (2011) The Australian Curriculum Information Sheet: A world-class curriculum for the 21st century. Sydney: Australian Curriculum Assessment and Reporting Authority.

ACARA (Australian Curriculum Assessment and Reporting Authority) (2017) Australian Curriculum F-10, version 8.3. Sydney: Australian Curriculum Assessment and Reporting Authority.

Aspin, D. (2002) 'An ontology of values and the humanization of education'. In Pascoe, S. Values in Education. Deakin West, ACT: Australian College of Educators, 128-30.

Australian Human Rights Commission (2014) Face the Facts: Cultural diversity. Sydney: Australian Human Rights Commission.

Banks, J.A. (2008) 'Diversity, group identity, and citizenship education in a global age'. Educational Researcher, 37 (3), 129-39.

Barron, B. and Darling-Hammond, L. (2008) 'Teaching for meaningful learning: A review of research on inquiry based and cooperative learning'. In Darling-Hammond, L., Barron, B., Pearson, P.D., Schoenfeld, A.H., Stage, E.K., Zimmerman, T.D., Cervetti, G.N. and Tilson, J.L. Powerful Learning: What we know about teaching for understanding. San Francisco: Jossey-Bass, 11-70.

Boix Mansilla, V. and Jackson, A. (2011) Educating for Global Competence: Preparing our youth to engage the world. New York: Asia Society.

Bourn, D. (2016) 'Teachers as agents of social change'. International Journal of Development Education and Global Learning, 7 (3), 63-77.

Camicia, S.P. and Franklin, B.M. (2011) 'What type of global community and citizenship? Tangled discourses of neoliberalism and critical democracy in curriculum and its reform'. Globalisation, Societies and Education, 9 (3-4), 311-22.

Carano, K.T. (2013) 'Global educators' personal attribution of a global perspective'. Journal of International Social Studies, 3 (1), 4-18. 
Cogan, J.J. and Grossman, D.L. (2009) 'Characteristics of globally minded teachers: A twenty-first century view'. In Kirkwood-Tucker, T.F. (ed.) Visions in Global Education: The globalization of curriculum and pedagogy in teacher education and schools: Perspectives from Canada, Russia, and the United States. New York: Peter Lang, 240-55.

Colvin, R.L. and Edwards, V. (2018) Teaching for Global Competence in a Rapidly Changing World. New York: Asia Society / OECD.

Crick, B. (2007) 'Citizenship: The political and the democratic'. British Journal of Educational Studies, 55 (3), 235-48.

De Oliveira Andreotti, V. (2011) 'The political economy of global citizenship education'. Globalisation, Societies and Education, 9 (3-4), 307-10.

De Oliveira Andreotti, V. and De Souza, L.M.T.M. (eds) (2012) Postcolonial Perspectives on Global Citizenship Education. New York: Routledge.

Fairclough, N. (2003) Analysing Discourse: Textual analysis for social research. London: Routledge.

Ferguson-Patrick, K., Reynolds, R. and MacQueen, S. (2018) 'Integrating curriculum: A case study of teaching global education'. European Journal of Teacher Education, 41 (2), 187-201.

Fullan, M. and Langworthy, M. (2014) A Rich Seam: How new pedagogies find deep learning. London: Pearson.

Goren, H. and Yemini, M. (2017) 'The global citizenship education gap: Teacher perceptions of the relationship between global citizenship education and students' socio-economic status'. Teaching and Teacher Education, 67, 9-22.

Heafner, T.L. and Fitchett, P.G. (2015) 'Principals' and teachers' reports of instructional time allocations in third grade'. Journal of International Social Studies, 5 (1), 81-100.

Kennedy, K. (2012) 'Global trends in civic and citizenship education: What are the lessons for nation states?' Education Sciences, 2, 121-35.

Lingard, B. and Keddie, A. (2013) 'Redistribution, recognition and representation: Working against pedagogies of indifference'. Pedagogy, Culture and Society, 21 (3), 427-47.

Lorenzini, M. (2013) 'From global knowledge to global civic engagement'. Journal of Political Science Education, 9 (4), 417-35.

Loughran, J. (2006) Developing a Pedagogy of Teacher Education: Understanding teaching and learning about teaching. London: Routledge.

MacQueen, S. and Ferguson-Patrick, K. (2015) 'Where's the action in global education? Employing global education for lasting change through teacher education'. In Reynolds, R., Bradbery, D., Brown, J., Carroll, K., Donnelly, D., Ferguson-Patrick, K. and MacQueen, S. (eds) Contesting and Constructing International Perspectives in Global Education. Rotterdam: Sense Publishers, 115-24.

Marshall, T.H. (1964) Class, Citizenship, and Social Development: Essays by T.H. Marshall. Westport, CT: Greenwood Press.

Martin, F. and Pirbhai-Illich, F. (2015) 'Service learning as post-colonial discourse: Active global citizenship'. In Reynolds, R., Bradbery, D., Brown, J., Carroll, K., Donnelly, D., Ferguson-Patrick, K. and MacQueen, S. (eds) Contesting and Constructing International Perspectives in Global Education. Rotterdam: Sense Publishers, 135-50.

MCEETYA (Ministerial Council on Education, Employment, Training and Youth Affairs) (2006) Statements of Learning for Civics and Citizenship. Melbourne: Curriculum Corporation.

MCEETYA (Ministerial Council on Education, Employment, Training and Youth Affairs) (2008) Melbourne Declaration on Educational Goals for Young Australians. Melbourne: Ministerial Council on Education, Employment, Training and Youth Affairs.

Merryfield, M. (2010) 'A meeting on the Congo: Race, voice and representation'. In Heilman, E. (ed.) Social Studies and Diversity Education: What we do and why we do it. New York: Routledge, 182-4.

Nussbaum, M.C. (2009) 'Education for profit, education for freedom'. Liberal Education, 95 (3), 6-13.

OECD (Organisation for Economic Co-operation and Development) (2018) Preparing Our Youth for an Inclusive and Sustainable World: The OECD PISA global competence framework. Paris: OECD Publishing.

Osler, A. (2011) 'Teacher interpretations of citizenship education: National identity, cosmopolitan ideals, and political realities'. Journal of Curriculum Studies, 43 (1), 1-24.

Osler, A. and Vincent, K. (2002) Citizenship and the Challenge of Global Education. Stoke-on-Trent: Trentham Books.

Oxfam UK (2015) Education for Global Citizenship. A guide for schools. Online. www.oxfam. org.uk/education/resources/education-for-global-citizenship-a-guide-for-schools (accessed 13 April 2019). 
Oxley, L. and Morris, P. (2013) 'Global citizenship: A typology for distinguishing its multiple conceptions'. British Journal of Educational Studies, 61 (3), 301-25.

Pashby, K. (2012) 'Questions for global citizenship education in the context of the "new imperialism": For whom, by whom?'. In De Oliveira Andreotti, V. and De Souza, L.M.T.M. (eds) Postcolonial Perspectives on Global Citizenship Education. New York: Routledge, 9-26.

Pike, G. (2015) 'Re-imagining global education in the neoliberal age: Challenges and opportunities'. In Reynolds, R., Bradbery, D., Brown, J., Carroll, K., Donnelly, D., Ferguson-Patrick, K. and MacQueen, S. (eds) Contesting and Constructing International Perspectives in Global Education. Rotterdam: Sense Publishers, 11-25.

Print, M. (2015) 'A global citizenship perspective through a school curriculum'. In Reynolds, R., Bradbery, D., Brown, J., Carroll, K., Donnelly, D., Ferguson-Patrick, K. and MacQueen, S. (eds) Contesting and Constructing International Perspectives in Global Education. Rotterdam: Sense Publishers, 187-98.

Rapoport, A. (2015) 'Global citizenship education: Classroom teachers' perspectives and approaches'. In Harshman, J., Augustine, T. and Merryfield, M. (eds) Research in Global Citizenship Education. Charlotte, NC: Information Age Publishing, 119-36.

Rapoport, A. (2017) 'Perception of global citizenship among international participants of study abroad programs'. World Studies in Education, 18 (1), 5-21.

Reynolds, R. (2015) 'One size fits all? Global education for different educational audiences'. In Reynolds, R., Bradbery, D., Brown, J., Carroll, K., Donnelly, D., Ferguson-Patrick, K. and MacQueen, S. (eds) Contesting and Constructing International Perspectives in Global Education. Rotterdam: Sense Publishers, 27-41.

Saavedra, A.R. and Opfer, V.D. (2012) 'Learning 21st-century skills requires 21st-century teaching'. Phi Delta Kappan, 94 (2), 8-13.

Schulz, W., Ainley, J., Fraillon, J., Losito, B., Agrusti, G. and Friedman, T. (2018) Becoming Citizens in a Changing World: IEA International Civic and Citizenship Education Study 2016 international report. Cham: Springer. Online. www.springer.com/gb/book/9783319739625 (accessed 13 April 2019).

Schweisfurth, M. (2006) 'Education for global citizenship: Teacher agency and curricular structure in Ontario schools'. Educational Review, 58 (1), 41-50.

Scott, C.L. (2015) The Futures of Learning 3: What kind of pedagogies for the 21st century? (ERF Working Paper 15). Paris: UNESCO Education Research and Foresight.

Subedi, B. (2010) 'Introduction: Reading the world through critical global perspectives'. In Subedi, B. (ed.) Critical Global Perspectives: Rethinking knowledge about global societies. Charlotte, NC: Information Age Publishing, 1-18.

UNESCO (United Nations Educational, Scientific and Cultural Organization) (2014) Global Citizenship Education: Preparing learners for the challenges of the 21st century. Paris: United Nations Educational, Scientific and Cultural Organization.

UNESCO (United Nations Educational Scientific and Cultural Organization) (2015) Global Citizenship Education: Topics and learning and objectives. Online. http://unesdoc.unesco.org/ images/0023/002329/232993e.pdf (accessed 13 April 2019).

Varadharajan, M. and Buchanan, J. (2017) 'Any small change? Teacher education, compassion, understandings and perspectives on global development education'. International Journal of Development Education and Global Learning, 9 (1), 33-48.

Voogt, J. and Roblin, N.P. (2012) 'A comparative analysis of international frameworks for 21 st century competences: Implications for national curriculum policies'. Journal of Curriculum Studies, 44 (3), 299-321.

Westheimer, J. and Kahne, J. (2004) 'What kind of citizen? The politics of educating for democracy'. American Educational Research Journal, 41 (2), 237-69.

Zong, G., Wilson, A.H. and Quashiga, A.Y. (2008) 'Global education'. In Levstik, L.S. and Tyson, C.A. (eds) Handbook of Research in Social Studies Education. New York: Routledge, 197-216. 


\section{Appendix}

\section{Table 1: Search terms}

\begin{tabular}{|c|c|c|}
\hline Phrase & Keyword/s & Synonyms \\
\hline \multirow[t]{2}{*}{ global citizens } & global & $\begin{array}{l}\text { world } \\
\text { international }\end{array}$ \\
\hline & citizen/s & $\begin{array}{l}\text { roles } \\
\text { responsible } \\
\text { responsibility/ies } \\
\text { community } \\
\text { social }\end{array}$ \\
\hline \multirow[t]{3}{*}{ learn in the world } & learn & develop \\
\hline & in & about \\
\hline & world & $\begin{array}{l}\text { globe } \\
\text { planet } \\
\text { Earth }\end{array}$ \\
\hline reflect in the world & reflect & $\begin{array}{l}\text { consider } \\
\text { compare } \\
\text { clarify } \\
\text { think } \\
\text { ponder }\end{array}$ \\
\hline participate in the world & participate & $\begin{array}{l}\text { engage } \\
\text { involve } \\
\text { act } \\
\text { perform } \\
\text { undertake } \\
\text { complete }\end{array}$ \\
\hline \multirow[t]{3}{*}{ addressing issues/ and acting } & address & $\begin{array}{l}\text { act/ing } \\
\text { work/ing } \\
\text { solv/e/ing } \\
\text { fix/ing } \\
\text { Improv/e/ing } \\
\text { chang/e/ing }\end{array}$ \\
\hline & issue/s & $\begin{array}{l}\text { problem } \\
\text { challenge } \\
\text { difficulty/ies } \\
\text { controversy/controversial } \\
\text { topic } \\
\text { subject }\end{array}$ \\
\hline & act/ing & $\begin{array}{l}\text { do/ing } \\
\text { participat/e/ing } \\
\text { involv/e/ing/ed/ment } \\
\text { perform/ance } \\
\text { engag/e/ment }\end{array}$ \\
\hline \multirow[t]{2}{*}{ critically examine } & critically & $\begin{array}{l}\text { critical } \\
\text { critique }\end{array}$ \\
\hline & examine & $\begin{array}{l}\text { view } \\
\text { study }\end{array}$ \\
\hline sustained engagement & sustain/ed & $\begin{array}{l}\text { prolonged } \\
\text { in-depth } \\
\text { longitudinal }\end{array}$ \\
\hline
\end{tabular}




\begin{tabular}{|c|c|c|}
\hline Phrase & Keyword/s & Synonyms \\
\hline & engagement & $\begin{array}{l}\text { involve/ment } \\
\text { participation } \\
\text { commitment } \\
\text { long term }\end{array}$ \\
\hline \multirow[t]{2}{*}{ real-world events } & real-world & $\begin{array}{l}\text { authentic } \\
\text { community } \\
\text { society }\end{array}$ \\
\hline & events & $\begin{array}{l}\text { current affairs } \\
\text { news } \\
\text { situations }\end{array}$ \\
\hline \multirow[t]{2}{*}{ interdisciplinary approach } & interdisciplinary & $\begin{array}{l}\text { disciplines } \\
\text { integrate/d } \\
\text { cross-curriculum }\end{array}$ \\
\hline & approach & $\begin{array}{l}\text { focus } \\
\text { study } \\
\text { theme }\end{array}$ \\
\hline \multirow[t]{2}{*}{ collaborat/e/ing and negotiat/e/ing } & collaborat/e/ing & $\begin{array}{l}\text { cooperat/e/ing } \\
\text { work/ing with } \\
\text { team } \\
\text { group }\end{array}$ \\
\hline & negotiat/e/ing & $\begin{array}{l}\text { resolv/e/ing } \\
\text { talk/ing } \\
\text { discuss/ing } \\
\text { solv/e/ing } \\
\text { communicat/e/ing }\end{array}$ \\
\hline diverse groups & divers/e/ity & $\begin{array}{l}\text { different } \\
\text { cross-cultural } \\
\text { multicultural } \\
\text { international } \\
\text { cultur/e/al }\end{array}$ \\
\hline technology & technol/ogical/ogies & $\begin{array}{l}\text { ICT } \\
\text { computer/s } \\
\text { digital } \\
\text { e-learning } \\
\text { multimodal }\end{array}$ \\
\hline
\end{tabular}

